\title{
INDUCING THE IN VITRO ROOTING OF SAGO PALM (Metroxylon sagu Rottb.) USING AUXIN
}

\section{Induksi Perakaran In Vitro pada Tanaman Sagu (Metroxylon sagu Rottb.) dengan Auksin}

Teuku Tajuddin, Karyanti, Tati Sukarnih, Nadirman Haska

Biotech Center BPPT, Building 630 PUSPIPTEK Area, Setu, Tangerang Selatan, Banten 15314

E-mail: teuku.tajuddin@bppt.go.id

\begin{abstract}
ABSTRAK
Tanaman sagu (Metroxylon sagu Rottb.) memiliki potensi yang besar sebagai sumber pangan, energi dan bahan baku industri. Kultur jaringan tanaman sagu telah dilakukan di Balai Pengkajian Bioteknologi BPPT dalam rangka perbanyakan genotipe atau aksesi unggul secara massal. Namun demikian, kendala utama yang dihadapi pada perbanyakan in vitro tanaman sagu adalah sulitnya pembentukan akar. Penelitian ini bertujuan untuk mendapatkan kombinasi hormon yang tepat dalam menginduksi perakaran tanaman sagu in vitro. Tunas anakan muda $(15-20 \mathrm{~cm})$ yang diperoleh dari daerah Rangkasbitung, Provinsi Banten digunakan sebagai eksplan. Dalam penelitian ini perakaran in vitro diinduksi dengan berbagai perlakuan jenis dan konsentrasi hormon auksin, konsentrasi medium dan jenis agar. Sebagai medium dasar digunakan medium Gamborg. Hasil penelitian menunjukkan bahwa konsentrasi IBA dan NAA yang terbaik adalah pada taraf 35 ppm. Selanjutnya Gelrite memberikan respon yang positif dengan munculnya perakaran pada pangkal eksplan.
\end{abstract}

Kata Kunci: Induksi perakaran, jenis agar, kultur in vitro, auksin, sagu

\begin{abstract}
Sago palm (Metroxylon sagu Rottb) has huge potential as food, energy and industrial bioresources. In vitro culture of sago palm was performed in Biotech Center, BPPT in order to obtain a large-scale of mass clonal propagation of superior genotypes. Nevertheless, the main obstacle for the sago palm in vitro propagation was rooting formation. The purpose of our study was to obtain the best hormones combination for root induction on sago palm shoots in vitro. The young suckers $(15-20 \mathrm{~cm})$ obtained from Rangkasbitung area, Banten Province, were used as explants. In our study, in vitro rooting was induced by different types and concentrations of auxin, medium strength and solidifying agents. The shoots were cultured on Gamborg media. The result showed that the best level of both hormones IBA and NAA for root induction was $35 \mathrm{ppm}$. Moreover the solidifying agent of Gelrite gave positive response by stimulating root at the basal-end.
\end{abstract}

Keywords: Rooting induction, solidifying agent, in vitro cultures, auxin, sago palm 


\section{INTRODUCTION}

Sago palm is the original plant from Southeast Asia, and has a huge potential as food and energy bioresources, as well as raw material for various industries. This palm is recognized as the mankind's oldest food plant with the starch contained in the trunk used as a staple food in Southeast Asia.

The starch production of sago palm is 3 to 4 times higher than rice, corn or wheat, and 17 times higher than cassava (Karim 2008). In order to support the food security program and to fulfill the national food consumption, it is important to develop the non-rice food crops as an alternative source of carbohydrates and food diversification. The sago palm is one of those prospective plants that have attracted the government attention as the alternative non-rice food crop, with the environmental conserved function. This palm was included in the program to accelarate its development (Direktorat Jenderal Perkebunan 2013). The starch of sago in $100 \mathrm{~g}$ contains some nutrition such as: 285 calori, $77 \mathrm{~g}$ water, 0.2 $\mathrm{g}$ protein, $30 \mathrm{mg}$ calsium, $71 \mathrm{~g}$ carbohydrate, $0.7 \mathrm{mg} \mathrm{Fe}$ and $0.3 \mathrm{~g}$ fiber (Johnson 2010).

Natural sago forest is wide spread in large area in Maluku and Papua regions. Bintoro (2003) stated that high quality sago palm, with high starch productivity, can only be found in those regions. Sago palm has many advantages over other starchproducing crops especially for its higher yield, grows along riverbanks and in swampy areas which are not suitable for other crops. Moreover, for the benefit of plantation no regular replanted is needed.

Sago palm is propagated generatively by seed and vegetatively by suckers. Since there are little number of seed found in the fruit bunch and low rate of seed germination ability, production of seedling from seed is not recommended. The result of germination study showed that the seed had low germination rate outcome, which was only 3.50 to $6.43 \%$ (Limbongan et al. 2005). Moreover, sago palm propagation by seed will resulted in high genotypic variation.

Vegetative propagation using suckers is a common practice and preference for sago palm farmers (Wahid 1987; Kanro et al. 2003). This type of propagation can produce seedlings that have the same characteristic as their mother plants. As seedling resources, suckers can be obtained from mature sago tree that going to be cut down for starch harvesting. The suckers that usually used for seedling are already 1 one year-old with $\pm 1 \mathrm{~m}$ in height, $3-5 \mathrm{~kg}$ in weight and 10 to $15 \mathrm{~cm}$ in diameter. Rooting is induced traditionally by immersing the suckers in running water or river for 2-4 weeks, or sometimes more, depending on the roots development (Mashud 1991). In nurseries, the mortality rate of suckers is around $20-40 \%$. In the dry season, higher mortality rates are common (Jong 1995). Trimming of roots to as short as $1 \mathrm{~cm}$ did not affect the subsequent survival of the suckers. Trimming of the rhizomes close to the growing point of the sucker was deleterious. When planting of suckers was delayed, treatment with a wide-spectrum fungicide while storing the suckers in cool and moist places was proved can reduce their mortality rate.

Nevertheless supplying seedling derived from the old and large suckers is challenging, since the amount of the old suckers is only a few in one mature tree. In contrary, from one mature sago tree, there are a lot of small and young suckers available. The small and young suckers though can only be induced using artificial media via plant tissue culture. Using in vitro culture technology, the small and young suckers can be stimulated to provide vigor and high quality planting materials.

To fulfill market demand, and to some extend, to prevent its extinction, sago palm plantation need to be developed by planting elite varieties in other areas. For these reasons a large number of seedlings are needed. Using the in vitro culture and high qualities mother plants, qualified seedling can be generated. In vitro propagation of sago palm has been conducted by many researchers using embryos (Hisajima et al. 1991), through somatic embryogenesis (Tahardi et al. 2002; Riyadi et al. 2005; Sumaryono et al. 2012) and direct shooting (Tajuddin et al. 2015). The problem arises when the in vitro sago shoots are usually weak with few roots or no root at all, and have low survival rates during acclimatization. The roots are important during acclimatization stage, so plantlet can 
pass this period with success. The purpose of this study was to obtain the best hormones combination for root induction on sago palm shoots via in vitro culture.

\section{MATERIALS AND METHODS}

\section{Plant materials}

Research activity was performed in Plant Tissue Culture Laboratory, Biotech Center BPPT, located in Puspiptek, Setu, Tangerang Selatan, Banten Province. For the purpose of in vitro propagation, samples of sago suckers, as long as $7-10 \mathrm{~cm}$, were taken from Rangkasbitung area, Banten Province. The sucker sterilization was conducted as described by Tajuddin et al. (2014).

\section{Rooting induction Experiment 1}

As explant resources, the sago palm shoots were prepared by in vitro culture as performed by Tajuddin et al. (2015) which had no any roots yet. The selected explants were subsequently transferred into rooting induction media containing auxin. In this experiment, several kinds of auxin were applied in high concentration as a single factor. Kinds of auxin were IAA (indole-3acetic acid), IBA (indole-3-butyric acid) and NAA (naphthaleneacetic acid), with the concentration ranged from $15,20,25,30,35$ upto $40 \mathrm{ppm}$ in B5 media (Gamborg et al. 1976). The explants were cut at the basalend point to increase their surface area in contact with media. Variables observed were percentage of rooted explants, number of root obtained, length of root, and color of root. All treatments were repeated for 5 times.
In the second experiment, two kinds of auxin, NAA and IBA, were applied in combination treatments. The concentration levels of NAA were 1.0, 1.5, 2.0, $2.5 \mathrm{ppm}$. Whilst IBA, in low concentration, were 0.25 and $0.5 \mathrm{ppm}$. The third factor was medium strengths, which were normal concentration (full strength) and half of normal concentration (half strength). The basic media used was B5 (Gamborg et al. 1976). The fourth factor was solidifying agent, which was applied when a semi solid medium was required. The solidifying agents used were Agar and Gelrite. The experimental design was illustrated in Table 1.

Ascorbic acid and casein hydrolisate were added into the media, but not as treatment factors. The same as previous experiment, the explants used were shoots without any roots. The explants were cut at the basal-end point to increase the surface contact with media.

Variables observed were percentage of rooted explants, number of root obtained, length of root, and color of root. The treatment repetition was 3 times.

\section{Experiment 3}

Based on the results obtained from experiment 1 , the experiment 3 was designed in order to find the right formula of auxin for root formation by selecting the range of IBA concentration in narrow scale. The auxin of IBA was applied as a single treatment, and ranged as $33,33.5,34,34.5$, $35,35.5,36,36.5,37$ and $37.5 \mathrm{ppm}$. The explants used were shoots without any roots. The explants were cut at the basal-end point to increase their surface area in contact with media. Variables observed were percentage of rooted explants, number of root obtained,

\section{Experiment 2}

Table 1. Treatment combination of growth hormones, medium strength and solidifying agents

\begin{tabular}{|c|c|c|c|c|c|c|c|c|c|}
\hline \multirow{3}{*}{$\begin{array}{l}\text { Medium } \\
\text { Strength }\end{array}$} & \multirow{3}{*}{$\begin{array}{l}\text { IBA } \\
\text { (ppm) }\end{array}$} & \multicolumn{8}{|c|}{ NAA (ppm) } \\
\hline & & \multicolumn{4}{|c|}{ Solidifying Agent: Agar (A) } & \multicolumn{4}{|c|}{ Solidifying Agent: Gelrite (G) } \\
\hline & & 1 & 1.5 & 2 & 2.5 & 1 & 1.5 & 2 & 2.5 \\
\hline \multirow{2}{*}{$\begin{array}{l}\text { Half Strength } \\
\text { Medium }(\mathrm{H})\end{array}$} & 0.25 & HA1 & HA2 & HA3 & HA4 & HG1 & HG2 & HG3 & HG4 \\
\hline & 0.5 & HA5 & HA6 & HA7 & HA8 & HG5 & HG6 & HG7 & HG8 \\
\hline \multirow{2}{*}{$\begin{array}{l}\text { Full Strength } \\
\text { Medium (F) }\end{array}$} & 0.25 & FA1 & FA2 & FA3 & FA4 & FG1 & FG2 & FG3 & FG4 \\
\hline & 0.5 & FA5 & FA6 & FA7 & FA8 & FG5 & FG6 & FG7 & FG8 \\
\hline
\end{tabular}


length of root, and color of root. All treatments were repeated for 10 times.

\section{RESULTS AND DISCUSSION}

\section{Experiment 1}

In order to pass the acclimatization phase and to be successful after planting in the field, the root system has to be established on the plantlets or seedlings. In our study, the rooting system was induced by growth hormones in sago shoots derived from in vitro culture. The growth hormones were selected from auxin class, such as NAA, IAA and IBA, which function in roots stimulation. These kinds of auxin are also commonly applied for rooting induction on many other plants in tissue cultures media. For this experiment, the concentration of auxin was applied in high concentration, given that in low concentration had no response in our previous initial trials, although having 2 months incubation in culture room. The observation results of our experiment are exposed in Table 2. It shows that the treatment of IBA 15, 25, 30, 35,40 , as well as NAA 30,35 and 40 gave positive responses. Rooting emerged from the basal-end of shoots, which differ in number and length. The root color was also gradually fluctuated from red to green in color. While the treatments of IAA at all level of concentration had no response on root initiation (data not shown).

Based on the types of growth hormones applied, only NAA and IBA gave positive responses. IBA stimulated growth of root from the concentration level of 15 to $40 \mathrm{ppm}$, whereas the concentration of 35 ppm induced the highest number of roots. NAA induced rooting from the concentration level of 30 to $40 \mathrm{ppm}$. Based on the number of root and rooting performance, the best level of both hormones was $35 \mathrm{ppm}$. Roots were emerged from shoots started from red swollen structure at the basal end in the 6 th week, then changed into small red roots on the 8th week. Comparing the shoot to each other, the emergence of roots were observed at various time. First swollen structure was examined on the IBA $35 \mathrm{ppm}$ treatment. On the $12 \mathrm{nd}$ week, the root became larger, longer, with hairy roots, and still red in color. While on the 16th week, the root color changed to green, and after 24th week the shoots (or plantlets) were ready to transfer into the green house for acclimatization phase (Figure 1).

Different timing of root formation among treatments may be as a result of different concentration of growth hormone added, as well as physiological differences

Table 2. The results of auxins concentration for rooting formation in sago shoots

\begin{tabular}{lcccccc}
\hline $\begin{array}{l}\text { Hormone } \\
(\mathrm{ppm})\end{array}$ & $\begin{array}{c}\text { Shoot } \\
\text { response }\end{array}$ & $\begin{array}{c}\text { Explants } \\
\text { with roots }\end{array}$ & $\begin{array}{c}\text { Average no. } \\
\text { of roots }\end{array}$ & $\begin{array}{c}\text { Root } \\
\text { Color }\end{array}$ & $\begin{array}{c}\text { Length of } \\
\text { root }(\mathrm{cm})\end{array}$ & $\begin{array}{c}\% \\
\text { Rooting }\end{array}$ \\
\hline IBA 15 & Rooting & 1 & 6 & Red & $0.2-0.5$ & 20 \\
IBA 20 & No & 0 & 0 & - & - & 0 \\
IBA 25 & Rooting & 3 & 6 & Greenish Red & $0.2-2.3$ & 60 \\
IBA 30 & Rooting & 1 & 8 & Brownish Red & $0.5-1$ & 20 \\
IBA 35 & Rooting & 3 & 7.3 & Green & $0.2-2.2$ & 60 \\
IBA 40 & Rooting & 3 & 2.6 & Reddish Green & $0.3-1.5$ & 60 \\
NAA 15 & No & 0 & 0 & - & 0 & 0 \\
NAA 20 & No & 0 & 0 & - & 0 & 0 \\
NAA 25 & No & 0 & 0 & - & 0 & 0 \\
NAA 30 & Rooting & 2 & 6 & Green & $0.2-3$ & 40 \\
NAA 35 & Rooting & 3 & 2 & Reddish Green & $0.2-4.5$ & 60 \\
NAA 40 & Rooting & 1 & 2 & Reddish Green & $0.7-1.2$ & 20 \\
\hline
\end{tabular}



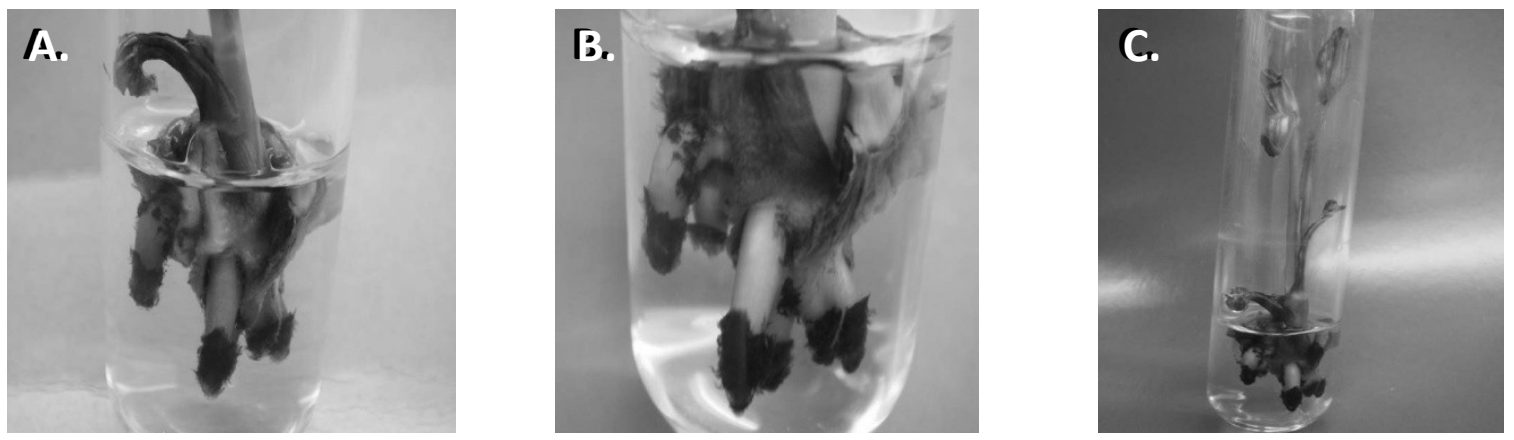

Figure 1. Roots formation on treatment IBA 35 ppm, which roots are red in color $(\mathrm{A})$; the root color turn to green (B); the plantlet ready for acclimatization phase (C)

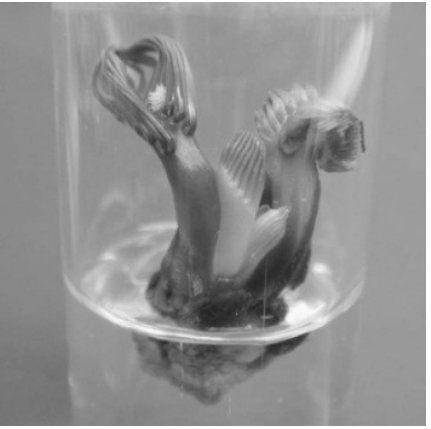

Figure 2. New shoots appearence on the explants at the end of experiment period, $24^{\text {th }}$ week

of sago shoots. The average time to establish roots formation, from the first emergence up to ready for acclimatization, was 4 to 5 months. For other treatment that did not producing any root, was maintained its freshness until the end of experiment period. The shoots were green in color and the increased in height. Surprisingly, still new shoots were initiated on that treatment (Figure 2).

\section{Experiment 2}

The rooting experiment was performed in order to find the best formulation of growth hormones for inducing rooting system in sago shoots in vitro. Similar to our previous work, in this experiment, two kinds of auxin were added, NAA and IBA. Instead of using high concentration of auxin, this time the concentration applied was low, lesser than $3 \mathrm{ppm}$. In combination, the level of NAA was slightly higher than IBA. The result of experiment is shown in Table 3.

It clearly shows that the solidifying agent of Agar has negative response on rooting formation. All treatment that cultured on Agar media did not induce any
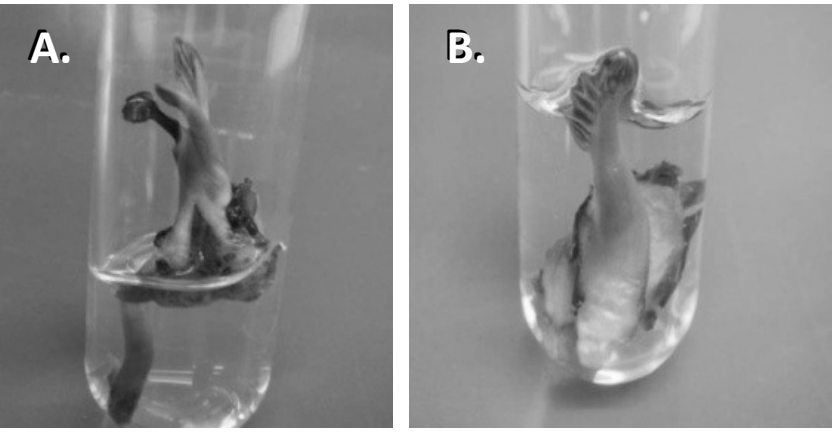

Figure 3. Root formation at the base of sago shoot on Gelrite treatment. Half strength $(A)$, and full strength (B)

roots, eventhough some treatments indicated the swollen structure at the basal end (treatment HA1, HA2 and HA5).

On the other hand, the solidifying agent Gelrite gave positive response by stimulating the swollen structure followed by the root appearance at the basal-end, regardless the concentration of basic media. Gelrite was high purity solidifying agent, while the Agar used was the commersially purchased Agar. The different composition between these solidifying agents may result in different response of rooting formation.

Both half strength and full strength of basic media concentration, producing swollen structure at the basal end, as well as the root formation (Figure 3 ). It seems that the difference of osmotic potential among these two media had no effect on the growth of sago shoots and roots initiation.

\section{Experiment 3}

This experiment was a continuation of rooting induction treatment in Experiment 1, which was concluded that adding $35 \mathrm{ppm}$ IBA into the shoot culture resulted in the best root formation. 
Table 3. Effect of auxins concentration in basic media and kind of solidifying agents on roots formation at sago shoots

\begin{tabular}{|c|c|c|c|c|c|c|}
\hline Treatment & $\begin{array}{l}\text { Response on } \\
\text { basal end }\end{array}$ & $\begin{array}{c}\text { Shoots with } \\
\text { root }\end{array}$ & $\begin{array}{c}\text { Average root } \\
\text { number }\end{array}$ & $\begin{array}{l}\text { Root } \\
\text { color }\end{array}$ & $\begin{array}{l}\text { Root length } \\
(\mathrm{cm})\end{array}$ & $\begin{array}{c}\text { Swollen } \\
\text { basal end }\end{array}$ \\
\hline HA1 & Swollen & - & - & - & - & 2 \\
\hline HA2 & Swollen & - & - & - & - & 2 \\
\hline HA3 & - & - & - & - & - & - \\
\hline HA4 & - & - & - & - & - & - \\
\hline HA5 & Swollen & - & - & - & - & 1 \\
\hline HA6 & - & - & - & - & - & - \\
\hline HA7 & - & - & - & - & - & - \\
\hline HA8 & - & - & - & - & - & - \\
\hline HG1 & Rooting & 1 & 1 & Red & 0.2 & 2 \\
\hline HG2 & Rooting & 1 & 1 & Red & 0.6 & 2 \\
\hline HG3 & - & - & - & - & - & - \\
\hline HG4 & - & - & - & - & - & - \\
\hline HG5 & - & - & - & - & - & - \\
\hline HG6 & Swollen & - & - & - & - & 3 \\
\hline HG7 & Swollen & - & - & - & - & 3 \\
\hline HG8 & Swollen \& Red & - & - & - & - & 3 \\
\hline FA1 & - & - & - & - & - & - \\
\hline FA2 & - & - & - & - & - & - \\
\hline FA3 & - & - & - & - & - & - \\
\hline FA4 & - & - & - & - & - & - \\
\hline FA5 & - & - & - & - & - & - \\
\hline FA6 & - & - & - & - & - & - \\
\hline FA7 & - & - & - & - & - & - \\
\hline FA8 & - & - & - & - & - & - \\
\hline FG1 & Rooting & 1 & 1 & Red & 1.1 & 2 \\
\hline FG2 & Swollen \& Red & - & - & - & - & 3 \\
\hline FG3 & - & - & - & - & - & - \\
\hline FG4 & Rooting & 1 & 1 & Red & 1.5 & 2 \\
\hline FG5 & - & - & - & - & - & - \\
\hline FG6 & - & - & - & - & - & - \\
\hline FG7 & Swollen \& Red & - & - & - & - & 3 \\
\hline FG8 & - & - & - & - & - & - \\
\hline
\end{tabular}

Note: Treatment codes are refer to Table 1 (Materials \& Methods)

In this experiment, the range of IBA concentration was narrowly outlined, in order to observe its effect on rooting formation specifically. The outcome of this experiment was similar to the result of Experiment 1.
Only the treatment of IBA $35 \mathrm{ppm}$ showed swollen structure at basal-end of shoot, which was red in color. The concentration of IBA, either lower or higher than $35 \mathrm{ppm}$, did not show any positive effect on rooting 


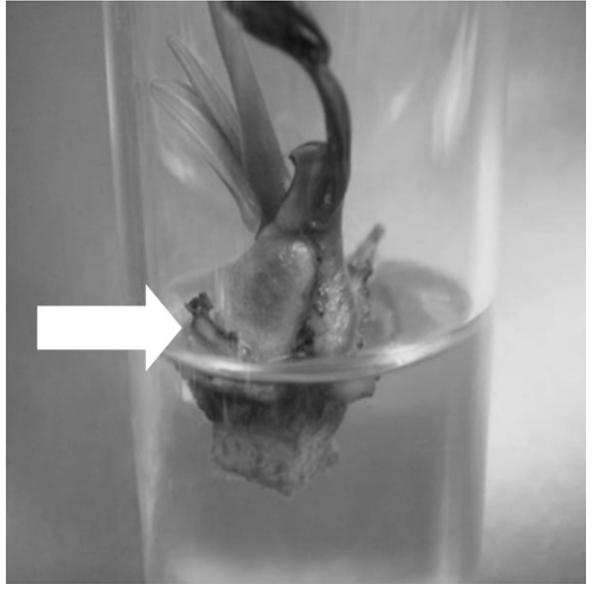

Figure 4. Swollen structure appearance (white arrow) at the basal end of shoot on the treatment IBA 35 ppm

formation. It seems that the concentration of $35 \mathrm{ppm}$ was the precise level of IBA to induce rooting on sago shoots. Swollen structure was formed after 8 weeks of culture.

The result from previous experiment indicated that after 8th week, the swollen structure developed into roots. Roots system soon expanded and elongated. Figure 4 presents the response of treatment IBA 35 ppm to sago shoots.

\section{CONCLUSION}

From our research activities it can be concluded that the best treatment for inducing root was IBA at the concentration of $35 \mathrm{ppm}$. Moreover, the solidifying agent Gelrite gave positive response by stimulating the root formation. Rooting emerged from the basal-end of shoots, which varied in number and length. The root color was also gradually changed from red to green in color.

\section{ACKNOWLEDGMENTS}

This work was supported by research collaboration between PT Sampoerna Bio Energi and Biotech Center BPPT on the Establishment of Tissue Culture System of Sago Palm.

\section{REFERENCES}

Direktorat Jenderal Perkebunan (2013) Peningkatan produksi, produktivitas dan mutu tanaman tahunan: Pedoman teknis pengembangan tanaman sagu.
Pedoman teknis pengembangan tanaman sagu tahun 2014. Direktorat Jenderal Perkebunan, Kementerian Pertanian, $24 p$

Bintoro MH (2003) Potensi pemanfaatan sagu untuk industri dan pangan. Prosiding Seminar Nasional Sagu, Manado 06 Oktober 2003. Pusat Penelitian dan Pengembangan Perkebunan. Bogor

Gamborg OL, Murashige T, Thorpe TA, Vasil IK (1976) Plant tissue culture media. In Vitro 12:473-478

Hisajima S, Jong FS, Arai Y, Sim ES (1991) Propagation and breeding of sago palm (Metroxylon sagu Rottb) plant in vitro: 1. Embryo culture and induction of multiple shoots from sago embryos in vitro. Jap J Trop Agric 35:259-267

Johnson DV (2010) Tropical palms. 2010 revision. Food and Agricultural Organization of United Nation. 242p

Jong FS (1995) Research for the development of sago palm (Metroxylon sagu Rottb) cultivation in Sarawak, Malaysia. PhD Thesis, Wageningen Univ. 139p

Kanro MZ, Rouw A, Widjono A, Syamsuddin, Amisnaipa, Ateka (2003) Tanaman sagu dan pemanfaatannya di Propinsi Papua. J Litbang Pertanian 22:116124

Karim AA, Tie AP, Manan DMA, Zaidul ISM (2008) Starch from sago (Metroxylon sagu) palm tree - Properties, prospect and challenges as a new industrial source for food and other uses. Comprehensive Reviews in Food Sci \& Food Safety 7:215-228

Limbongan J, Hanafiah A, Nggobe M (2005) Pengembangan sagu Papua. Balai Pengkajian Teknologi Pertanian Papua. Badan Penelitian dan Pengembangan Pertanian. Departemen Pertanian

Mashud N (1991) Faktor-Faktor yang harus diperkirakan untuk membudidayakan tanaman sagu. Balai Penelitian Kelapa. Badan Penelitian dan Pengembangan Pertanian. Departemen Pertanian. Manado. Buletin Balitka No 13: 111-116

Riyadi I, Tahardi JS, Sumaryono (2005) The development of somatic embryos of sago palm (Metroxylon sagu Rottb) on 
solid media. Menara Perkebunan 73:33-40

Sumaryono, Muslihatin W, Ratnadewi D (2012) Effect of carbohydrate source on growth and performance of in vitro sago palm (Metroxylon sagu Rottb) plantlets. Hayati J Biosci 19:88-92

Tahardi JS, Sianipar NF, Riyadi I (2002) Somatic embryogenesis in sago palm (Metroxylon sagu Rottb). In: K Kaimuna, M Okazaki, Y Toyoda, JE Cecil (eds.), New Frontiers of Sago Palm Studies, p. 75-81. Universal Academic Press, Inc. Tokyo, Japan Tajuddin T, Karyanti, Sukarnih T, Haska N
(2014) A revised method for sucker sterilization to support the in vitro propagation of sago palm (Metroxylon sagu Rottb). J Bioteknol Bios Indon 1:21-26

Tajuddin T, Karyanti, Sukarnih T, Haska N (2015) The combination of growth hormones increased in vitro shoots multiplication on sago palm (Metroxylon sagu Rottb). J Bioteknol Bios Indon 2:73-79

Wahid AS (1987) Pengaruh besar anakan, naungan dan penyimpanan terhadap pertumbuhan bibit tanaman sagu (Metroxylon sagu Rottb). Tesis. Fakultas Pertanian, IPB, Bogor 